\title{
The Role of IL28B Genotype in HCV-RNA Baseline Levels
}

\author{
Lucio Boglione Jessica Cusato Giovanni Di Perri Antonio D'Avolio \\ Department of Infectious Diseases, Amedeo di Savoia Hospital, University of Turin, Turin, Italy
}

Dear Editor,

The role of interleukin (IL)-28B has been described in the treatment response and the spontaneous clearance of hepatitis $\mathrm{C}$ virus (HCV) infection [1], but recently several studies have examined the effect of the IL28B genotype and the natural course of chronic hepatitis $\mathrm{C}(\mathrm{CHC})$, especially regarding the fibrosis progression and liver inflammation. In an interesting paper by Noureddin et al. [2] the IL28B rs12979860 CC genotype, already known for its higher response rate to pegylated interferon (PEGIFN) treatment, was associated with hepatic inflammation and worse clinical outcomes; also the rs8099917 GG genotype was associated with slower fibrosis progression than the TT genotype in Caucasian patients [3]. Another important contribution by Grebely et al. [4] highlighted the role of the IL28B genotype in HCV-RNA levels as an important factor that can affect the progression of fibrosis in $\mathrm{CHC}$; however, the role of IL28B in influencing the baseline viral load is still poorly understood and considered in clinical studies. Patients with CC or TT genotypes present a higher baseline viral load than CT/TT or TG/GG genotypes, despite a greater chance of viral clearance or response to PEG-IFN. Regarding this finding, in our previous published study we reported that the IL28B genotypes were related both to baseline viremia and to the presence or absence of mixed cryoglobulinemia [5]. Patients with the TT/CC ge- notype for rs12979860/rs8099917 showed a significant correlation with higher HCVRNA levels, the presence of mixed cryoglobulinemia and insulin resistance. Furthermore, in our cohort of 541 patients affected by $\mathrm{CHC}$ and treated with PEGIFN/ribavirin we retrospectively evaluated baseline HCV-RNA according to the combined genotypes of IL28B rs8099917 and rs 12979860. The results are as follows (fig. 1): 192 patients presented the TT/
CC genotype $(35.5 \%)$ with median $\mathrm{HCV}$ $\mathrm{RNA}=6.0 \log \mathrm{IU} / \mathrm{ml}(\mathrm{IQR} 5.4-7.2) ; 118$ had the TT/TC genotype (21.8\%) with median HCV-RNA = 5.6 log IU/ml (IQR 4.7$6.1) ; 133$ showed the TG/TC genotype (24.6\%) with median HCV-RNA = $5.2 \mathrm{log}$ IU/ml (IQR 4.5-5.8), and 35 patients had the GG/TT genotype (6.5\%), with median $\mathrm{HCV}-\mathrm{RNA}=4.8 \mathrm{log} \mathrm{IU} / \mathrm{ml}$ (IQR 3.4-5.3). All the differences among the IL28B combinations were statistically significant $(\mathrm{p}<$

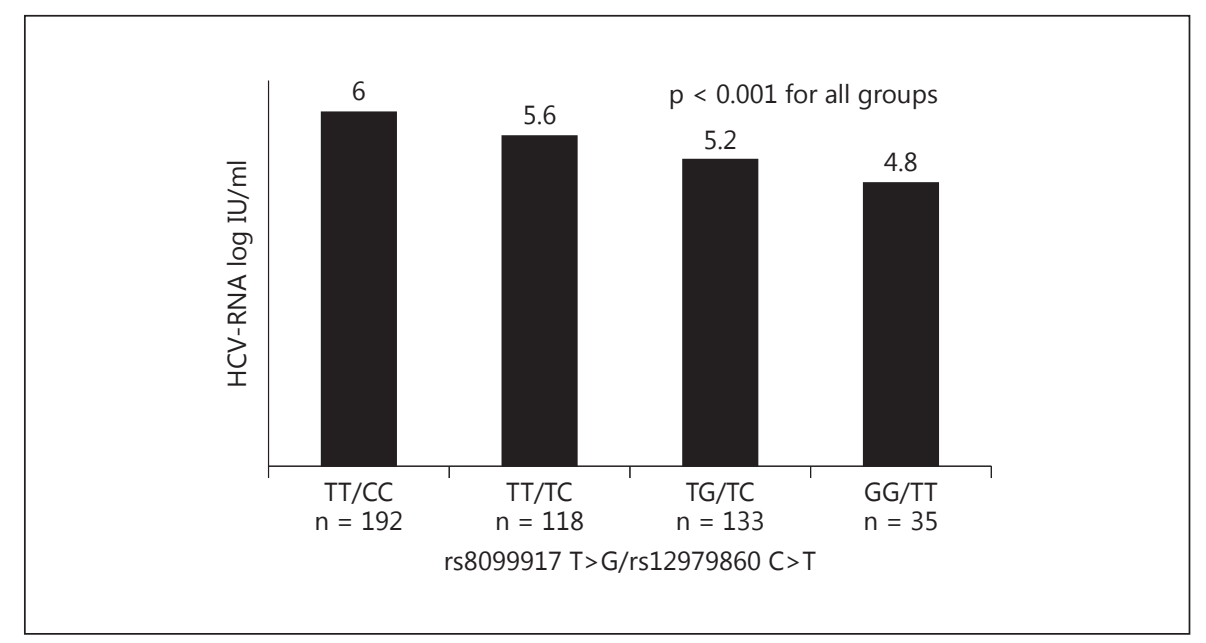

Fig. 1. Median baseline HCV-RNA levels according to different genotypes of IL28B rs8099917 and rs12979860 in 541 patients treated with PEG-IFN and ribavirin.

\section{KARGER}

E-Mail karger@karger.com www.karger.com/int (c) 2016 S. Karger AG, Base

$0300-5526 / 16 / 0000-0000 \$ 39.50 / 0$
Lucio Boglione, $\mathrm{MD}, \mathrm{PhD}$

Department of Infectious Diseases, Amedeo di Savoia Hospital University of Turin, Dogliotti 14 IT-10126 Turin (Italy)

E-Mail lucio.boglione@unito.it 
0.001). Surprisingly, the difference of HCVRNA between the favorable TT/CC and the unfavorable GG/TT profile is $1.2 \log \mathrm{IU} / \mathrm{ml}$, despite the greater clinical response observed in patients with the TT/CC genotype; this difference is greater than reported by Noureddin et al. [2] considering only the rs12979860 (0.16 log IU/ml). In multivariate analysis, the most predictive factor as-

\section{References}

1 Luo Y, Jin C, Ling Z, Mou X, Zhang Q, Xiang C: Association study of IL28B: rs 12979860 and rs8099917 polymorphisms with SVR in patients infected with chronic HCV genotype 1 to PEG-INF/RBV therapy using systematic meta-analysis. Gene 2013;513:292-296.

2 Noureddin M, Wright EC, Alter HJ, Clark S, Thomas E, Chen R, Zhao X, et al: Association of IL28B genotype with fibrosis progression and clinical outcomes in patients with chronic hepatitis C: a longitudinal analysis. Hepatology 2013;58:1548-1557. sociated with a higher baseline viral load (HCV-RNA $>800,000 \mathrm{IU} / \mathrm{ml}$ ) is precisely the TT/CC genotype (OR 6.05, 95\% CI $2.33-11.09, \mathrm{p}<0.001)$, while the presence of the $\mathrm{G}$ allele at rs8099917 is an independent predictive factor of low viral load (OR 18.06, 95\% CI 6.61-34.55, p < 0.001). We previously reported the same finding in HCV-4 patients, where the TT/CC geno- type was associated with a sustained viral response and GG/TT with a null-responder despite the lower baseline HCV-RNA [6]. In conclusion, we confirm the role of IL28B as a determinant of baseline viremia, but both rs8099917 and rs12979860 polymorphisms should be determined to better assess clinical outcomes, treatment response and the progression of liver fibrosis.
3 Bochud PY, Bibert S, Kutalik Z, Patin E, Guergnon J, Nalpas B, et al: IL28B alleles associated with poor hepatitis $\mathrm{C}$ virus (HCV) clearance protect against inflammation and fibrosis in patients infected with non-1 HCV genotypes. Hepatology 2012;55:384-394.

4 Grebely J, Grady B, Hajarizadeh B, Page K, Dore GJ: Disease progression during advanced fibrosis: IL28B genotype or HCV RNA levels? Hepatology 2014;59:1650-1651.
5 Boglione L, Cusato J, Allegra S, Cariti G, Di Perri G, D'Avolio A: Role of IL28B genotyping in patients with hepatitis $C$ virus-associated mixed cryoglobulinemia and response to PEG-IFN and ribavirin treatment. Arch Virol 2015;160:2009-2017.

6 Boglione L, Cusato J, De Nicolo A, Cariti G, Allegra S, Ghisetti V, Di Perri G, et al: Identification of naive HVC-4 patients who may be treated with pegylated-interferon and ribavirin according to IL28B polymorphisms. Antiviral Res 2014;106C:105-110. 